
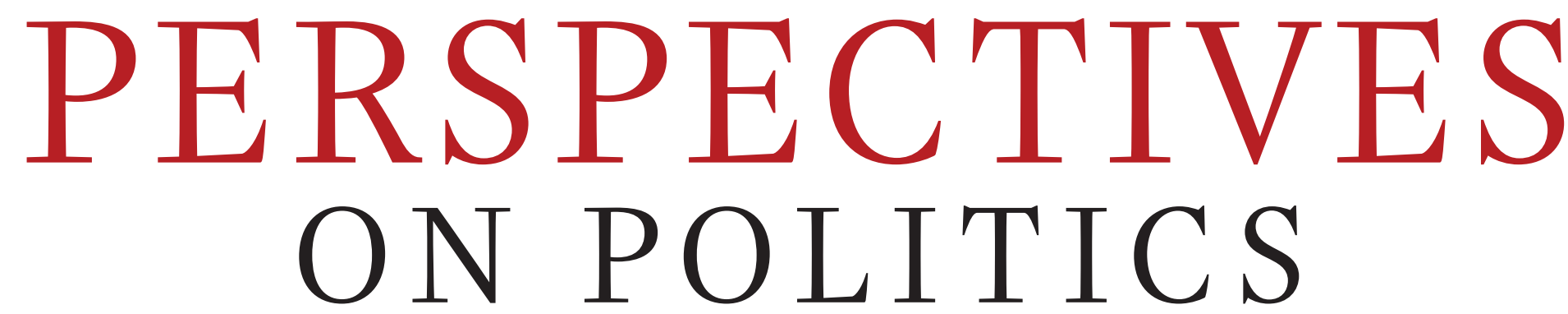

A Political Science Public Sphere | December 2010, Volume 8, Number 4

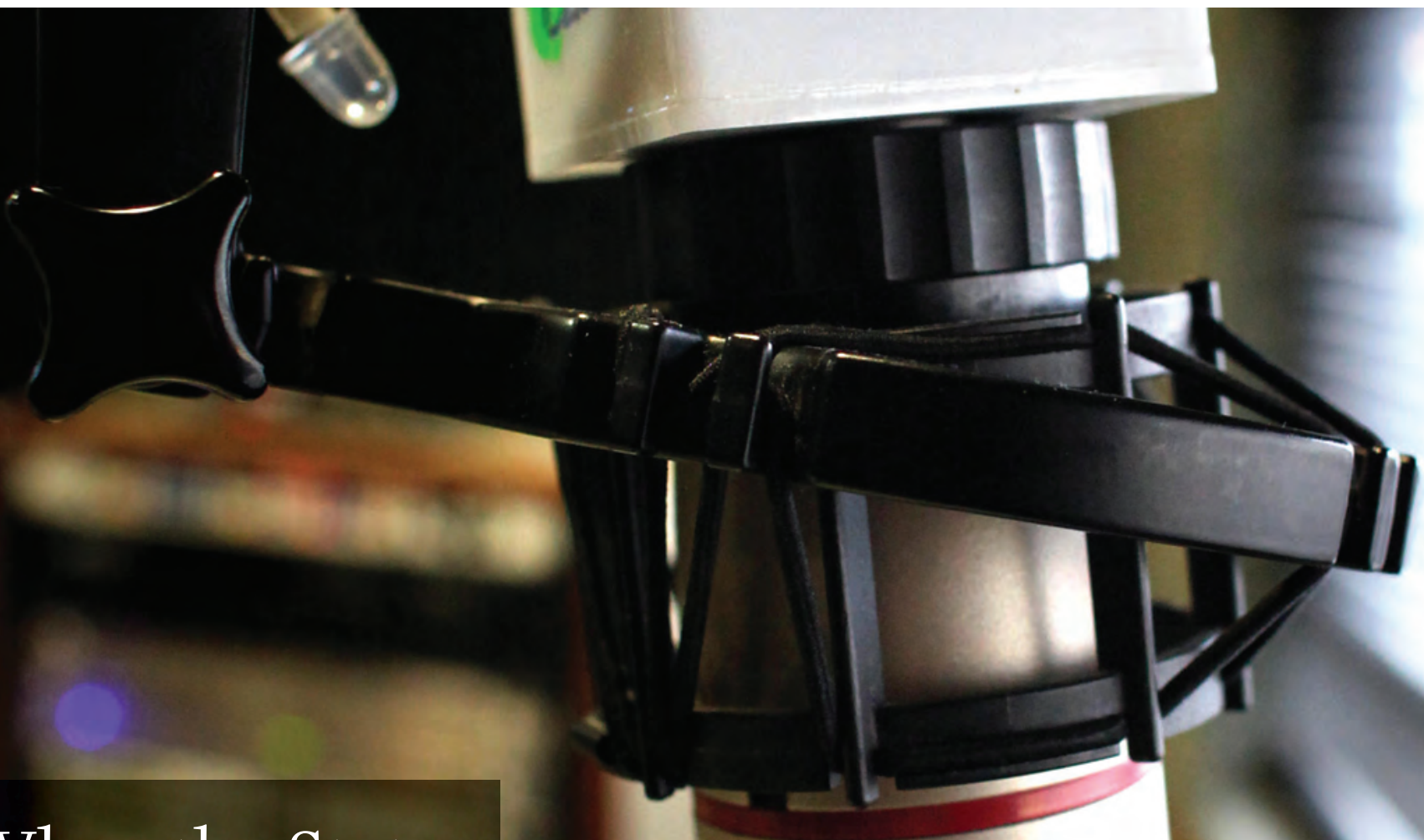

When the State Speaks, What Should It Say? The Dilemmas of Freedom of Expression and Democratic Persuasion Corey Brettschneider 


\section{American Political Science Association}

\section{APSA Membership Opens Doors}

Take Advantage of the Value of APSA Membership

\section{As the the oldest,}

\section{largest, and most}

\section{comprehensive}

political science

society in the

world, APSA

supports over

14,000 members

in 70 countries and advances

political science in

many ways.

\section{Open the door}

to your future.

Become an APSA

member!

\section{Offering Online Scholarship}

Scholarship is central to APSA membership.Current and recent back issues of all three APSA journals are available online to members through Cambridge Journals Online. Members can also gain access to the full historical collection through JSTOR subscriptions. Political Research Online (PROL), a collaborative project led by APSA and a consortium of political science and related associations, houses 30,000 searchable conference papers.

\section{Creating Networks and Connecting Scholars}

APSA strives to provide valuable opportunities for members to network with colleagues, share ideas, and form relationships to drive their careers. Members receive discounts for APSA conferences-the Teaching and Learning Conference, Conference for Chairs, and the Annual Meeting - as well as access to the association's Organized Sections.

\section{Providing Career and Employment Resources}

APSA's eJobs is the most comprehensive online resource of political science employment opportunities and job candidates. It is fully searchable and updated daily with new job listings and candidate resumes. The eJobs placement service at the Annual Meeting brings employers and candidates together in person to greatly facilitate the hiring process.

\section{Supporting Political Science Research}

The Centennial Center for Political Science \& Public Affairs, located at APSA's headquarters building, provides office space for scholars and students conducting field work in Washington, D.C. Through the Center, APSA also offers a number of research grant opportunities for scholars working in various subfields.

\section{Membership application, rates and details: www.apsanet.org/membership}

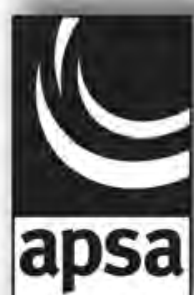




\section{Perspectives on Politics}

December 2010/Vol. 8, No. 4 | American Political Science Association

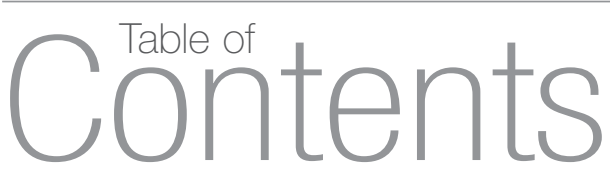

\section{Editor's Introduction}

1001 Editor's Introduction

Jeffrey C. Isaac

\section{Articles}

1005 When the State Speaks, What Should It Say? The Dilemmas of Freedom of Expression and Democratic Persuasion

Corey Brettschneider

1021 Exit Rights and Entrance Paths: Accommodating Cultural Diversity in a Liberal Democracy Sigal Ben-Porath

1035 The Dark Side of American Liberalism and Felony Disenfranchisement Mary Fainsod Katzenstein, Leila Mohsen Ibrahim, and Katherine D. Rubin

1055 Redefining Russia: Hybrid Regimes, Fieldwork, and Russian Politics J. Paul Goode

\section{Reflections Symposium}

1077 Puzzles versus Problems: The Alleged Disconnect between Academics and Military Practitioners Michael W. Mosser

1087 Writing Culture Doctrine: Public Anthropology, Military Policy, and World Making Robert Albro

1095 Scholars and Security

Paul Bracken

1101 Social Science Research and Military Agendas: Safe Distance or Bridging a Troubling Divide? Craig Calhoun

1107 The Risks of Scholarly Militarization: A Feminist Analysis Cynthia Enloe

Cover Art: An unattended microphone is pictured inside the studio of CNB in Caracas on August 2, 2009 , after 34 radio stations were shut down by the government for "operating illegally." According to Reuters, Venezuelan President Hugo Chavez declared that "We haven't closed any radio stations, we've applied the law. We've recovered a bunch of stations that were outside the law, that now belong to the people and not the bourgeoisie." (http://www.reuters.com/ article/idUSN0146551720090801, accessed 10/29/2010) Chavez has articulated an emphatically anti-liberal understanding of the state's authority to speak and to determine the limits of free expression. (Photo by Thomas Coex / AFP / Getty Images) 
1113 Striking the Right Balance: Of High Walls and Divisions of Labor

Ronald R. Krebs

1117 Critical Thinking and Its Discontents

Paul Yingling

1123 Author's Response

Michael W. Mosser

\section{Reflections}

1125 The Mindsets of Political Compromise

Amy Gutmann and Dennis Thompson

\section{Review Essay}

1145 Legislative Obstruction

David R. Mayhew

\section{Review Symposium}

1155 Soviet Studies, National Security and the Production of "Useful" Knowledge

A Discussion of Know Your Enemy: The Rise and Fall of America's Soviet Experts

By David C. Engerman

Stephen E. Hanson

Karen L. Dawisha

Michael D. Kennedy

\section{Critical Dialogue}

1167 Reviews and Responses

Robert Jervis

Why Intelligence Fails: Lessons from the

Iranian Revolution and the Iraq War

James H. Lebovic

The Limits of U.S. Military Capability: Lessons from Vietnam and Iraq

1175 Reviews and Responses

Daniel Jordan Smith

A Culture of Corruption: Everyday Deception

Eric M. Uslaner

and Popular Discontent in Nigeria

Corruption, Inequality, and the Rule of Law:

The Bulging Pocket Makes the Easy Life

\section{Book Reviews}

\section{HUMAN RIGHTS}

1181 Scott Barclay, Mary Bernstein, and Anna-Maria Marshall, eds. Queer Mobilizations: LGBT Activists Confront the Law. Review by Susan Gluck Mezey

1182 Michael Barnett and Thomas G. Weiss, eds. Humanitarianism in Question: Politics, Power, Ethics.

Clifford Bob, ed. The International Struggle for New Human Rights.

Eric A. Heinze, Waging Humanitarian War: The Ethics, Law, and Politics of Humanitarian Intervention. Review by Richard Devetak

1184 Charles R. Beitz and Robert E. Goodin, eds. Global Basic Rights.

Review by Michael Goodhart 
1186 Jay Bergman, Meeting the Demands of Reason: The Life and Thought of Andrei Sakharov. Review by Daniel J. Mahoney

1187 Judith Butler, Frames of War: When Is Life Grievable?

Austin Sarat and Jennifer L. Culbert, eds. States of Violence: War, Capital Punishment, and Letting Die. Review by Dustin Ells Howes

1190 Elizabeth F. Cohen, Semi-Citizenship in Democratic Politics. Review by Lawrie Balfour

1191 Bruce P. Frohnen and Kenneth L. Grasso, eds. Rethinking Rights: Historical, Political, and Philosophical Perspectives. Review by James Bernard Murphy

1192 Carol Harrington, The Politicization of Sexual Violence: From Abolitionism to Peacekeeping. Review by R. Charli Carpenter

1193 Kimberly A. Hudson, Justice, Intervention, and Force in International Relations: Reassessing Just War Theory in the $21^{\text {st }}$ Century. Review by Antonio Y. Vázquez-Arroyo

1195 David Kinley, Civilising Globalisation: Human Rights and the Global Economy. Review by Rhoda E. Howard-Hassmann

1196 Joseph E. Luders, The Civil Rights Movement and the Logic of Social Change. Review by Christopher S. Parker

1198 Wiktor Osiatyński, Human Rights and Their Limits. Review by Sonu Bedi

1199 Christopher S. Parker, Fighting for Democracy: Black Veterans and the Struggle against White Supremacy in the Postwar South. Review by Joseph E. Luders

1200 Apichai W. Shipper, Fighting for Foreigners: Immigration and Its Impact on Japanese Democracy. Review by Martin A. Schain

1202 Kathleen Staudt, Violence and Activism at the Border: Gender, Fear, and Everyday Life in Ciudad Juárez. Review by Nancy A. Naples

1203 Roger Wertheimer, ed. Empowering Our Military Conscience: Transforming Just War Theory and Military Moral Education. Review by Celestino Perez

1205 Richard Ashby Wilson and Richard D. Brown, eds. Humanitarianism and Suffering: The Mobilization of Empathy. Review by Hugo Slim

\section{POLITICAL THEORY}

1206 Jeff J. S. Black, Rousseau's Critique of Science: A Commentary on the Discourse on the Sciences and the Arts. Review by Jonathan Marks

1207 Richard Bourke and Raymond Geuss, eds. Political Judgement: Essays for John Dunn.

John M. Parrish, Paradoxes of Political Ethics: From Dirty Hands to the Invisible Hand. Review by David L. Marshall

1209 Jorge J. E. Gracia, ed. Race or Ethnicity? On Black and Latino Identity. Review by Juliet Hooker

1211 Jeffrey Edward Green, The Eyes of the People: Democracy in an Age of Spectatorship. Review by Margaret Kohn

1212 A. James Gregor, Marxism, Fascism, and Totalitarianism: Chapters in the Intellectual History of Radicalism.

Zeev Sternhell. Translated by David Maisel, The Anti-Enlightenment Tradition. Review by George Crowder

1214 Russell Hardin, How Do You Know? The Economics of Ordinary Knowledge. Review by Mark B. Brown

1215 Karuna Mantena, Alibis of Empire: Henry Maine and the Ends of Liberal Imperialism.

Thomas McCarthy, Race, Empire, and the Idea of Human Development. Review by Daniel I. O'Neill

1217 Eric Nelson, The Hebrew Republic: Jewish Sources and the Transformation of European Political Thought. Review by Steven B. Smith

1219 Melvin L. Rogers, The Undiscovered Dewey: Religion, Morality, and the Ethos of Democracy. Review by Colin Koopman

1220 Takashi Shogimen and Cary J. Nederman, eds. Western Political Thought in Dialogue with Asia. Review by Theresa Man Ling Lee

1222 Marc Stears, Demanding Democracy: American Radicals in Search of a New Politics. Review by Robert Westbrook

1223 Anna Stilz, Liberal Loyalty: Freedom, Obligation, and the State. Review by Steven Johnston

1224 Dana Villa, Public Freedom. Review by Dean Hammer 
AMERICAN POLITICS

1226 Alan I. Abramowitz, The Disappearing Center: Engaged Citizens, Polarization, and American Democracy.

Morris P. Fiorina with Samuel J. Abrams, Disconnect: The Breakdown of Representation in American Politics. Review by Frances E. Lee

1228 Beau Breslin, From Words to Worlds: Exploring Constitutional Functionality.

Review by Robert L. Tsai

1230 Bruce E. Cain, Todd Donovan, and Caroline J. Tolbert, eds. Democracy in the States: Experiments in Election Reform.

Alec C. Ewald, The Way We Vote: The Local Dimension of American Suffrage.

Michael J. Hanmer, Discount Voting: Voter Registration Reforms and Their Effects. Review by Edward M. Burmila

1232 Marty Cohen, David Karol, Hans Noel, and John Zaller, The Party Decides: Presidential Nominations Before and After Reform. Review by Steven S. Smith

1233 Donald L. Drakeman, Church, State, and Original Intent. Review by Carson Holloway

1235 Paul Frymer, Black and Blue: African Americans, the Labor Movement and the Decline of the Democratic Party. Review by Janice Fine

1236 Matthew Levendusky, The Partisan Sort: How Liberals Became Democrats and Conservatives Became Republicans. Review by Cindy D. Kam

1238 Nicole P. Marwell, Bargaining for Brooklyn: Community Organizations in the Entrepreneurial City. Review by Elisabeth S. Clemens

1239 Steven M. Teles, The Rise of the Conservative Legal Movement: The Battle for Control of the Law.

Brian J. Glenn and Steven M. Teles, eds. Conservatism and American Political Development. Review by Paul Pierson

1242 Sean M. Theriault, Party Polarization in Congress. Review by David Karol

1243 Robert L. Tsai, Eloquence and Reason: Creating a First Amendment Culture. Review by Beau Breslin

\section{COMPARATIVE POLITICS}

1245 John R. Bowen, Can Islam Be French? Pluralism and Pragmatism in a Secular State.

Jocelyne Cesari, ed. Muslims in the West after 9/11: Religion, Politics and Law.

Shamit Saggar, Pariah Politics: Understanding Western Radical Islamism and What Should Be Done. Review by Jytte Klausen

1247 Young Nam Cho, Local People's Congresses in China: Development and Transition. Review by Daniela Stockmann

1248 Richard F. Doner, The Politics of Uneven Development: Thailand's Economic Growth in Comparative Perspective. Review by Erik Martinez Kuhonta

1250 Susan Greenhalgh, Just One Child: Science and Policy in Deng's China. Review by Carrie Liu Currier

1251 James Habyarimana, Macartan Humphreys, Daniel N. Posner, and Jeremy Weinstein, Coethnicity: Diversity and the Dilemmas of Collective Action.

Review by Steven Wilkinson

1252 Stephen E. Hanson, Post-Imperial Democracies: Ideologies and Party Formation in Third Republic France, Weimar Germany, and Post-Soviet Russia. Review by Sidney Tarrow

1254 Jude C. Hays, Globalization and the New Politics of Embedded Liberalism.

Quan Li and Rafael Reuveny, Democracy and Economic Openness in an Interconnected System: Complex Transformations. Review by Jeffry A. Frieden

1257 Orit Kedar, Voting for Policy, Not Parties: How Voters Compensate for Power Sharing. Review by James Adams

1259 Mikhail Myagkov, Peter C. Ordeshook, and Dimitri Shakin, The Forensics of Election Fraud: Russia and Ukraine. Review by Alan Renwick

1260 Nadya Nedelsky, Defining the Sovereign Community: The Czech and Slovak Republics.

John A. Scherpereel, Governing the Czech Republic and Slovakia: Between State Socialism and the European Union.

Martin Horak, Governing the Post-communist City: Institutions and Democratic Development in Prague. Review by Tim Haughton

1262 Gabriel Ondetti, Land, Protest, and Politics: The Landless Movement and the Struggle for Agrarian Reform in Brazil. Review by Paul Dosh

1263 Patricia M. Thornton, Disciplining the State: Virtue, Violence, and State-Making in Modern China. Review by Peter Hays Gries 
INTERNATIONAL RELATIONS

1264 Itty Abraham, ed. South Asian Cultures of the Bomb: Atomic Publics and the State in India and Pakistan. Review by Harsh V. Pant

1266 Eli Berman, Radical, Religious and Violent: The New Economics of Terrorism. Review by James A. Piazza

1267 Philip G. Cerny, Rethinking World Politics: A Theory of Transnational Neopluralism. Review by Miles Kahler

1269 Bruce Cumings, Dominion from Sea to Sea: Pacific Ascendancy and American Power. Review by Anatol Lieven

1270 Mark Galeotti, ed. The Politics of Security in Modern Russia. Review by Brian D. Taylor

1271 John Horgan, Walking Away from Terrorism: Accounts of Disengagement from Radical and Extremist Movements. Review by Mohammed M. Hafez

1273 Audrey Kurth Cronin, How Terrorism Ends: Understanding the Decline and Demise of Terrorist Campaigns.

Barak Mendelsohn, Combating Jihadism: American Hegemony and Interstate Cooperation in the War on Terrorism. Review by Ivan Arreguín-Toft

1275 Idean Salehyan, Rebels without Borders: Transnational Insurgencies in World Politics. Review by Jeffrey T. Checkel

1276 Narcís Serra, The Military Transition: Democratic Reform of the Armed Forces. Review by David Pion-Berlin

1277 Monica Duffy Toft, Securing the Peace: The Durable Settlement of Civil Wars. Review by Ron E. Hassner

1279 William T. Tow, ed. Security Politics in the Asia-Pacific: A Regional-Global Nexus? Review by Kai He

1280 David H. Ucko, The New Counterinsurgency Era: Transforming the U.S. Military for Modern Wars.

James Igoe Walsh, The International Politics of Intelligence Sharing. Review by Mark Phythian

1282 Barbara F. Walter, Reputation and Civil War: Why Separatist Conflicts Are So Violent. Review by Stacie E. Goddard

1285 Review Index 


\section{Philosophy for Perspectives on Politics}

Perspectives seeks to nurture a political science public sphere, publicizing important scholarly topics, ideas, and innovations, linking scholarly authors and readers, and promoting broad reflexive discussion among political scientists about the work that we do and why this work matters.

A full-length copy of the editorial philosophy appears in Perspectives on Politics 8(1): 7-10 and also on the web at http://www.apsanet.org/ content_44375.cfm.

\section{Submission and Review}

For submission guidelines, please see http://www.apsanet.org/ content_44360.cfm.

Our editorial team discusses all submissions. Those that seem promising are evaluated by several external reviewers - with full confidentiality on both sides - and then accepted, returned for further revisions, or declined with suggestions of more appropriate venues for publication.

\section{Perspectives on Politics}

\section{Editor}

Jeffrey C. Isaac, Indiana University, 2009-

Associate Editors

Edwina Barvosa, University of California, Santa Barbara

Richard Battistoni, Providence College

Daniel Drezner, Fletcher School, Tufts University

Page Fortna, Columbia University

Marc Morjé Howard, Georgetown University

Bryan Jones, University of Texas, Austin

Stathis Kalyvas, Yale University

Elizabeth S. Markovits, Mount Holyoke

Melissa Nobles, MIT

Timothy Kaufman-Osborn, Whitman College

Paul Pierson, University of California, Berkeley

James Scott, Yale University

Dara Strolovitch, University of Minnesota

Lisa Wedeen, University of Chicago

\section{Managing Editor}

\section{James Moskowitz}

Assistants to the Editor

Adrian Florea, Emily Hilty, Carolyn Holmes, Margot Morgan, Katie Scofield, Rebekah Tromble
Association Office Address and Membership Information: American Political Science Association individual membership dues are as follow: Regular members with income $\$ 100,000+, \$ 208 ; \$ 80,000-\$ 99,999, \$ 178 ; \$ 60,000-\$ 79,999$, $\$ 160 ; \$ 50,000-\$ 59,999, \$ 148 ; \$ 40,000-\$ 49,999$, \$126; less than $\$ 40,000, \$ 84$; Student members, $\$ 40$; Retired members with income $\$ 25,000+$, \$57: Retired members with income less than $\$ 25,000$, \$35; Life members: $\$ 3,000$; Unemployed members: \$40; Associate member with one journal selection $\$ 52$. The amount of the dues allocated for a subscription is $\$ 6$ for an individual membership. Changes of address for members should be completed online or mailed to the APSA membership office at: APSA, 1527 New Hampshire Avenue, N.W. Washington, DC 20036

Subscription, Publishing, and Advertising Office Address: Cambridge University Press, 32 Avenue of the Americas, New York, NY 10013; and (for correspondents outside the United States, Canada, and Mexico) Cambridge University Press, The Edinburgh Building, Shaftesbury Road, Cambridge CB2 8RU, England.

Subscription Information: Perspectives on Politics (ISSN 1537 5927) is published quarterly, in March, June, September, and December, by Cambridge University Press for the American Political Science Association. Annual institutional electronic-only subscription rate (2011) is US\$777 in the United States, Canada, and Mexico; £420 elsewhere. Annual institutional print-andelectronic subscription rate (2011) is US\$857 in the United States, Canada, and Mexico; $£ 458$ elsewhere. Perspectives on Politics is sold only as part of a joint subscription with the American Political Science Review and PS: Political Science \& Politics. Single part rate (2011) is US\$80 in the United States, Canada, and Mexico; £43 elsewhere. Periodicals postage rate paid at New York, NY, and additional mailing offices. Postmaster: Send address changes to Perspectives on Politics, Cambridge University Press, 100 Brook Hill Drive, West Nyack, NY 10994-2133, U.S.A.

(c) the American Political Science Association 2010

All rights reserved. No part of this publication may be reproduced, in any form or by any means, electronic, photocopying, or otherwise, without permission in writing from Cambridge University Press. Permission inquiries from the USA, Mexico, and Canada should be addressed to the New York office of Cambridge University Press http://www. cambridge. org/us/ information/rights/contacts/newyork.htm; permission inquiries from elsewhere should be addressed to the Cambridge office http:// www.cambridge.org/uk/information/rights/contacts/ cambridge.htm; permission inquiries from Australia and New Zealand should be addressed to the Melbourne office http:// uww.cambridge.org/aus/information/contacts_melbourne.htm.

Permission to copy (for users in the U.S.A) is available from the Copyright Clearance Center, http://www.copyright.com, email: info@copyright.com. Specific written permission must be obtained for republication; contact the nearest Cambridge University Press office.

Individual Copies: Single copies of Perspectives on Politics may be purchased for $\$ 25.00$

Microfilm Editions: Microfilm editions of Perspectives on Politics are available from ProQuest Information and Learning. Ann Arbor, Ml 48106. (800) 521-0600.

Advertising: Perspectives on Politics has a circulation of 16,000 . For information on advertising rates and mechanical requirements, contact Advertising Coordinator, Cambridge University Press, 32 Avenue of the Americas, New York, NY 10013. (212) 337-5000.

Composition: Beljan, Ltd., Dexter, MI.

Printing and Distribution: The Sheridan Press, Hanover, PA

Reprint Permissions: Reprints of Perspectives articles for class use are available through the Academic Permissions Service of the Copyright Clearance Center, 222 Rosewood Drive, Danvers, MA 01923; phone: (978) 750-8400; fax: (978) 7504744 ; or online at www.copyright.com. 


\section{American Political Science Association}

\section{Supporting Political Science Award Endowments}

APSA supports exceptional scholarship in the discipline by honoring those whose work stands above the rest. The Association's awards are made possible by the generous contributions of members and friends. Many of these awards were initially funded years ago. The time has come to strengthen the endowments that support them so that APSA can continue to make possible award amounts that convey the prestige associated with them. Endowments for the following awards are in need of an additional $\$ 5,000$ to $\$ 10,000$ each to reach the $\mathbf{\$ 2 5 , 0 0 0 ~ m i n i m u m ~ c u r r e n t l y ~ r e q u i r e d ~ o f ~ a l l ~ e n d o w m e n t s . ~ P l e a s e ~ c o n s i d e r ~ s u p p o r t i n g ~ t h e ~ d i s c i p l i n e ~ b y ~ d o n a t - ~}$ ing to one of these funds. Gifts are accepted as one-time donations or as pledges to be fulfilled over time. For more information on giving to APSA, visit www.apsanet.org/contribute or contact Allison Desrosiers at adesrosiers@apsanet.org or 202.483.2512.

\section{Gabriel A. Almond Prize}

The Gabriel A. Almond prize honors the best dissertation in comparative politics. The award was created in recognition of former APSA president Gabriel Almond's contributions to the discipline, profession, and Association. Almond's scholarly work contributed directly to the development of theory in comparative politics and brought together work on the developing areas and Western Europe that prevented splintering into an array of disparate areas studies.

\section{William Anderson Award}

The William Anderson prize honors the best dissertation in federalism or intergovernmental relations, state, and local politics. The award was set up in reognition of former APSA president William Anderson, who was a leading American authority in the areas of local government, public administration, intergovernmental relations, and the history of political science. He did much to shape teaching and research in these fields not only at his own university, but throughout the country.

\section{Carey McWilliams Award}

The Carey McWilliams prize recognizes a major journalistic contribution to our understanding of politics. Eligible candidates meet the criteria laid forth by the first organizing committee. First, the individual should have a distinguished public service career in newspaper, magazine, or broadcast media. Second, the individual should, in their work, illuminate some broad general principles of the social and political sciences. Third, the individual may have a background in editorial activities and not necessarily be a working journalist or writer. Fourth, the individual should illuminate certain key elements identified with McWilliams, which include intellectual forthrightness and political independence.

\section{Charles E. Merriam Award}

The Charles Merriam Award was established to recognize a person whose published work and career represent a significant contribution to the art of government through the application of social science research. Charles Merriam's career exemplified a combination of innovative political and social science scholarship and practical service to the community and nation. The department he chaired in the 1920s-1940s set the agenda of the political science profession in the post World War II decades. He was the key figure in the founding of the Social Science Research Council. His public service included membership in the Chicago City Council, and on President Roosevelt's National Resources Planning Board and the Committee on Administrative Management.

\section{E. E. Schattschneider Award}

The E. E. Schattschneider prize is awarded for the best doctoral dissertation completed and accepted during that year or the previous year in the field of American government. This award fund, established in 1971, was set up in honor of former APSA president Elmer Eric ("E. E.") Schattschneider, a widely published and respected political scientist. 


\section{About APSA}

Founded in 1903, the American Political Science Association is the leading professional organization for the study of political science and serves more than 15,000 members in over 80 countries. With a range of programs and services for individuals, departments, and institutions, APSA brings together political scientists from all fields of inquiry, regions, and occupational endeavors within and outside academe in order to expand awareness and understanding of politics.

The direct advancement of knowledge is at the core of APSA activities. We promote scholarly communication in political science through a variety of initiatives including publishing three distinguished journals: American Political Science Review, Perspectives on Politics, and PS: Political Science and Politics.

\section{Officers}

\section{PRESIDENT}

Carole Pateman

University of California, Los Angeles

\section{PRESIDENT-ELECT}

G. Bingham Powell Jr.

University of Rochester

\section{VICE-PRESIDENTS}

Larry M. Bartels

Princeton University

Luis Ricardo Fraga

University of Washington

Nancy L. Rosenblum

Harvard University

\section{SECRETARY}

Susan Peterson

College of William \& Mary

\section{TREASURER}

Arthur Lupia

University of Michigan

\section{PROGRAM CO-CHAIRS}

Frances Hagopian

University of Notre Dame

Bonnie Honig

Northwestern University

\section{EDITOR-IN-CHIEF, APSR}

Ronald Rogowski

University of California, Los Angeles

\section{EDITOR-IN-CHIEF,} PERSPECTIVES

Jeffrey Isaac

Indiana University

\section{EXECUTIVE DIRECTOR}

Michael Brintnall

American Political Science

Association

\section{Council}

\section{9-2011}

Cristina Beltrán

Haverford College

Yun-han Chu

Academia Sinica/National Taiwan University

Mark A. Graber

University of Maryland

Evelyne Huber

University of North Carolina,

Chapel Hill

Thomas E. Mann

Brookings Institution

Joseph P. McCormick II

Pennsylvania State University, York

Julie Novkov

State University of New York, Albany

S. Laurel Weldon

Purdue University

2010-2012

Jeffrey M. Berry

Tufts University

Michael C. Desch

University of Notre Dame

Christopher F. Gelpi

Duke University

Simon Hix

London School of Economics and Political Science

Mala Htun

The New School for Social Research

Anne Norton

University of Pennsylvania

Laura Katz Olson

Lehigh University

Dara Z. Strolovitch

University of Minnesota, Twin Cities

\section{Former APSA Presidents}

Frank J. Goodnow

Albert Shaw

Frederick N. Judson James Bryce

A. Lawrence Lowell

Woodrow Wilson

Simeon E. Baldwin

Albert Bushnell Hart

W. W. Willoughby

John Bassett Moore

Ernst Freund

Jesse Macy

Munroe Smith

Henry Jones Ford

Paul S. Reinsch

Leo S. Rowe

William A. Dunning

Harry A. Garfield

James W. Garner

Charles E. Merriam

Charles A. Beard

William Bennett Munro

Jesse S. Reeves

John A. Fairlie

Benjamin F. Shambaugh

Edward S. Corwin

William F. Willoughby

Isidor Loeb

Walter Shepard

Francis W. Coker

Arthur N. Holcombe

Thomas Reed Powell

Clarence A. Dykstra

Charles Grove Haines

Robert C. Brooks

Frederic A. Ogg

William Anderson

Robert E. Cushman

Leonard D. White

John Gaus

Walter F. Dodd

Arthur W. MacMahon

Henry R. Spencer

Quincy Wright

James K. Pollock

Peter H. Odegard

Luther Gulick

Pendleton Herring

Ralph J. Bunche

Charles McKinley

Harold D. Lasswell

E. E. Schattschneider

V. O. Key Jr.
R. Taylor Cole

Carl B. Swisher

Emmette S. Redford

Charles S. Hyneman

Carl J. Friedrich

C. Herman Pritchett

David B. Truman

Gabriel A. Almond

Robert A. Dahl

Merle Fainsod

David Easton

Karl W. Deutsch

Robert E. Lane

Heinz Eulau

Robert E. Ward

Avery Leiserson

Austin Ranney

James MacGregor Burns

Samuel H. Beer

John C. Wahlke

Leon D. Epstein

Warren E. Miller

Charles E. Lindblom

Seymour Martin Lipset

William H. Riker

Philip E. Converse

Richard F. Fenno Jr.

Aaron B. Wildavsky

Samuel P. Huntington

Kenneth N. Waltz

Lucian W. Pye

Judith N. Shklar

Theodore J. Lowi

James Q. Wilson

Lucius J. Barker

Charles O. Jones

Sidney Verba

Arend Lijphart

Elinor Ostrom

M. Kent Jennings

Matthew Holden Jr.

Robert O. Keohane

Robert Jervis

Robert D. Putnam

Theda Skocpol

Susanne Hoeber Rudolph Margaret Levi

Ira Katznelson

Robert Axelrod

Dianne M. Pinderhughes

Peter Katzentstein

Henry E. Brady 